\title{
EFEITOS DO SOMBREAMENTO ARBÓREO NAS CONDIÇÕES TERMO- HIGROMÉTRICAS E LUMÍNICAS DE AMBIENTES INTERNOS E EXTERNOS DE EDIFICAÇÕES
}

\author{
Luciane Durante \\ Professora do Departamento de Arquitetura e Urbanismo/ FAET/ UFMT, Doutora em Física Ambiental, Linha de \\ Pesquisa: Análise Microclimática em Sistemas Urbanos, E-mail: luciane.durante@hotmail.com

\section{Marta Cristina Jesus de Albuquerque Nogueira} \\ Professora do Departamento de Arquitetura e Urbanismo/ FAET/ UFMT, Professora do Programa de Pós-Graduação \\ em Física Ambiental, Linha de Pesquisa: Análise Microclimática em Sistemas Urbanos, E-mail: mcjanp@gmail.com
}

http://dx.doi.org/10.5902/223611707704

\section{RESUMO:}

A estratégia de sombreamento, em climas quentes, é um dos principais recursos da arquitetura bioclimática. Esta pesquisa teve por objetivo foi avaliar os efeitos da estratégia passiva de sombreamento arbóreo nas condições termo higrométricas e lumínicas de ambientes externos e internos de edificações. A metodologia consistiu da medição de variáveis ambientais a céu aberto, sob a copa de árvores e no interior de salas idênticas sombreadas e não sombreadas. Essas variáveis foram relacionadas às características morfofisiológicas dos indivíduos arbóreos e constatou-se melhoria das condições térmicas externas sob as copas e internamente às salas sombreadas. A atenuação da temperatura sob as copas proporcionada pelo Oiti e Mangueira foram de 1,3 e $1,5^{\circ} \mathrm{C}$, respectivamente. O Oiti, de índice de área foliar de $7,4 \mathrm{~m}^{2} / \mathrm{m}^{2}$ e área foliar total de $842,5 \mathrm{~m}^{2}$, sombreando fachada orientada a 318 , proporcionou temperatura interna na sala sombreada $1^{\circ} \mathrm{C}$ menor que na sala sem sombreamento. A Mangueira, de índice de área foliar $10,1 \mathrm{~m}^{2} / \mathrm{m}^{2}$ e área foliar total de $940,7 \mathrm{~m}^{2}$, sombreando fachada orientada a $263 \%$, proporcionou temperatura interna na sala sombreada $1,4^{\circ} \mathrm{C}$ menor que na sala sem sombreamento. Ocorreram perdas d iluminação natural nas salas sombreadas decorrentes do sombreamento arbóreo do Oiti e Mangueira, de 48 e $82 \%$, respectivamente. Os resultados mostram a significativa contribuição dos indivíduos arbóreos como mitigadores do microclima externo e interno, evidenciando a importância da arborização para cidades de clima quente. As perdas de iluminação natural podem ser compensadas com sistemas de iluminação eficientes que integrem a iluminação natural e artificial.

Palavras-chave: arquitetura bioclimática, iluminância, temperatura.

\section{EFFECTS OF CONDITIONS IN TERMS TREE SHADING-HYGROMETRIC LUMINOUS ENVIRONMENTS AND INTERNAL AND EXTERNAL BUILDING}

ABSTRACT:

The strategy of shading, in hot climates, is one of the main features of bioclimatic architecture. This research was aimed to evaluate the effects of passive strategy of the tree shading term hygrometric conditions and luminous of external and internal environments of buildings. The methodology consisted of measuring environmental variables in the open, under the canopy of trees and inside rooms identical shaded and unshaded. These variables were related 
to morphological and physiological characteristics of individual trees and found to improve the thermal conditions under the canopy outside and inside the shaded rooms. The attenuation of temperature under the canopy provided by Oiti and hose were 1.3 and $1.5^{\circ} \mathrm{C}$ respectively. The Oiti of leaf area index of $7.4 \mathrm{~m} 2 / \mathrm{m} 2$ and total leaf area of $842.5 \mathrm{~m} 2$, shading facade oriented to 318 , provided internal temperature in the room shaded $10 \mathrm{C}$ lower than the room without shading. The hose, leaf area index of $10.1 \mathrm{~m} 2 / \mathrm{m} 2$ and total leaf area of $940.7 \mathrm{~m} 2$, shading facade oriented $263 \circ$, provided internal temperature in the room shaded $1.4^{\circ} \mathrm{C}$ lower than the room without shading. There were losses $d$ natural lighting in rooms under the shaded tree shading Oiti and Hose, 48 and $82 \%$, respectively. The results show the meaningful contribution of individual trees as mitigators of external and internal microclimate, highlighting the importance of trees for warmweather cities. Losses of natural lighting can be offset with efficient lighting systems that integrate natural and artificial lighting.

Keywords: Bioclimatic architecture, illuminance, temperature.

\section{INTRODUÇÃO}

A cidade e os edifícios tiveram historicamente muitos modelos que se estabeleceram através dos tempos, acompanhando as mudanças culturais das sociedades. Atualmente, há uma tendência mundial de universalização da arquitetura dos edifícios, com pouca evidência de vínculos com o lugar em que a mesma se insere.

Os edifícios apresentam arquitetura padrão, que independe do clima dos locais em que são construídos, o que torna seus usos dependentes dos sistemas artificiais de condicionamento térmico e de iluminação, geralmente oriundos de tecnologias ativas.

Como consequência, o impacto desses edifícios em seus entornos é elevado. Alteram o balanço de energia em decorrência da substituição de vegetação nativa ou remanescente por materiais artificiais e vegetação projetada, do sombreamento que proporcionam, da mudança no comportamento da radiação refletida no entorno e pela produção de demanda extra de energia para sua ocupação, dentre outros (AYOADE, 2001; SANTANA NETO, 2000).

Desta forma, em cidades de clima quente, o ambiente construído - do interior das edificações ou externo a elas - apresentam tendências de elevação das temperaturas ambientais. Sabe-se, no entanto, que, mesmo em climas quentes e densamente construídos, é possível, por meio de recursos adequados, obter microclimas específicos, com condições mais amenas que o entorno - efeito oásis (DUARTE e SERRA, 2003). Essas condições podem ser intencionalmente projetadas, utilizando-se de áreas verdes, água, elementos de barreira ou captação do vento e sol, na escala urbana e do edifício, com objetivo de proporcionar melhor desempenho térmico das edificações e redução de consumo de energia para fins de condicionamento artificial.

A vegetação se apresenta, então, como um elemento mitigador do ponto de vista energético. Em condições tropicais, melhora o microclima, propiciando abrigo da radiação solar e dos ventos, diminuindo a temperatura do ar e incrementando a umidade (KOENIGSBERGER, 1974). Givoni (1992) afirma que além de satisfazer a necessidades humanas instintivas de proteção, as árvores contribuem para a melhoria do microclima imediato, citando o aspecto térmico como o maior benefício das árvores. Se forem densas, podem servir como barreira para o ruído, captar a poeira em suas folhas e filtrar o ar, proporcionar privacidade e controlar o iluminamento excessivo do sol. Nos climas quentes, as superfícies vegetadas e as folhas das árvores absorvem a radiação 
solar, o sombreamento reduz as temperaturas superficiais e, o processo de evapotranspiração diminui a temperatura do ar.

Diversas pesquisas têm sido realizadas, com diferentes metodologias, no intuito de demonstrar a influência da vegetação no microclima e as relações na qualidade térmica dos espaços urbanos abertos (BARTHOLOMEI, 2003; CRUZ e LOMBARDO, 2007; BORGES, 2009; LIMA, 2009; CALLEJAS et al. 2011).

Acerca do efeito da vegetação nos edifícios, segundo Akbari (2002), a vegetação adequadamente disposta em torno da edificação, durante o verão, impede que a radiação solar direta a atinja e, com isso, ocorre redução da energia gasta para resfriamento. O bloqueio da radiação difusa e refletida das superfícies do entorno alteram o balanço de energia da edificação, e durante o dia, os ganhos de calor são sempre reduzidos pelo sombreamento da vegetação, pois esta usa parte da energia absorvida para os processos de evapotranspiração e fotossíntese (PAPADAKIS et al.,2001).

A quantificação dos benefícios proporcionados pelo uso intencionado da vegetação no ambiente construído tem extrema importância, uma vez que as interações que ocorrem entre a vegetação e o ambiente construído são complexas e determinantes do desempenho termoenergético dos edifícios, sendo este tema estudado por HOYANO (1998), AYRES (2005), GUPTA et al. (2011) e YOSHIMI e ALTAN (2011).

Nesse sentido, Pietrobon (1999), realizou estudo que aborda o desempenho termoenergético de ambientes sombreados e não sombreados e as características da vegetação. O objetivo foi quantificar como a distância da árvore ao edifício, a iluminação artificial, a inércia e o isolamento térmico das paredes se comportavam frente às transparências variadas de copas arbóreas. A situação ótima indicada no estudo representou uma economia de energia anual da ordem de 14 a $17 \%$.

Cita-se também, as pesquisas de Chen (2006) e Piveta (2010), que estudaram o sombreamento por vegetação e concluíram que as contribuições da vegetação nas condições ambientais internas de edificações relacionam-se diretamente com o Índice de Área Foliar (IAF) da vegetação, o que demonstra a importância deste índice em estudos que envolvem o tema proposto neste trabalho.

O IAF é expresso pela relação entre a superfície foliar e a superfície de projeção da copa no solo $\left(\mathrm{m}^{2} / \mathrm{m}^{2}\right)$. O IAF define a intensidade da resposta da planta ao meio (OMETO, 1981), se relaciona com a quantidade de luz interceptada pela copa (CHARLES EDWARDS e THORNLEY, 1972) e influencia no fluxo de calor no solo e nas temperaturas superficiais das áreas sombreadas. Copas densas possuem IAF elevado e proporcionam menor fluxo de calor no solo sob a copa, bem como o inverso (YANG et al., 1999). Assim sendo, os benefícios da vegetação se estendem a qualquer tipo de clima e edifício, desde que adequadamente posicionada e especificada, e propicia benefícios à qualidade de vida de qualquer população.

Sabendo-se que, para o clima da cidade de Cuiabá, é recomendado sombreamento das aberturas e fachadas em 35\% das horas de conforto anuais no interior das construções (LIGGETT e MILNE, 2010), este estudo teve por objetivo avaliar os efeitos do sombreamento arbóreo nas condições termo higrométricas e lumínicas de ambientes externos e internos às edificações.

\section{MATERIAIS E MÉTODOS}

A pesquisa foi realizada nos Sítios 1 e 2 ilustrados na Figura 01, na zona urbana de Cuiabá/MT, nas coordenadas geográficas de $53^{\circ} 03^{\prime} \mathrm{O}, 15^{\circ} 33^{\prime} \mathrm{S}$ e $56^{\circ} 07^{\prime} \mathrm{O}, 15^{\circ} 35^{\prime} \mathrm{S}$, com altitudes de 233 e 179 m, respectivamente, distantes entre si de cerca de $4000 \mathrm{~m}$, em linha reta. Abrigam 
edificações escolares idênticas, implantadas no Sítio $1 \mathrm{com}$ as fachadas principal e secundária orientadas a $138^{\circ}$ e $318^{\circ}$ e, no Sítio 2 , a $83^{\circ}$ e 263으, respectivamente (Figura 01).

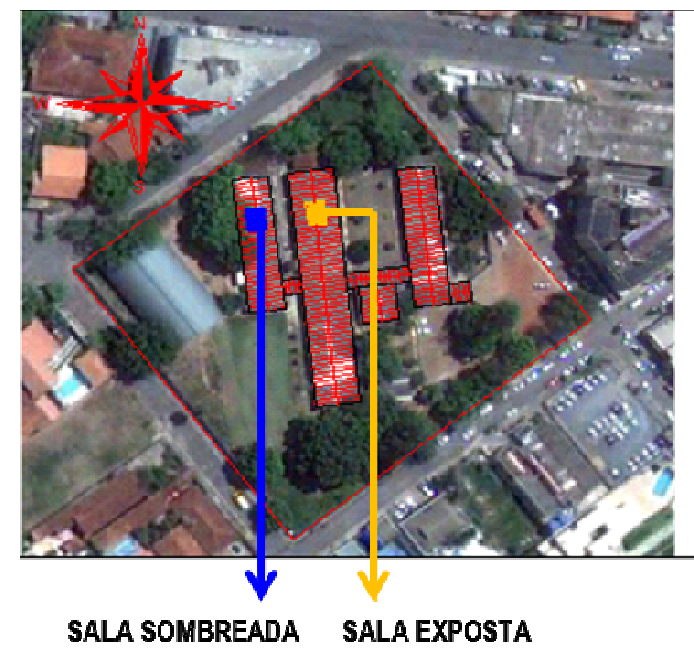

a)

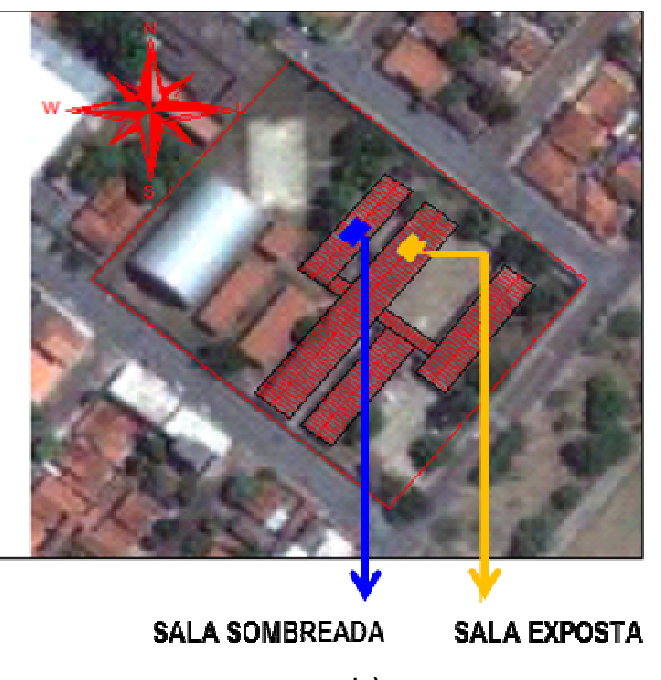

b)

Figura 01 - Posição relativa das salas com e sem sombreamento nos Sítios 1 (a) e 2 (b) Fonte: Adaptado de GOOGLE (2009)

Os objetos de pesquisa foram salas de aula de mesma posição relativa nas edificações, sendo uma sala sem e, outra, com sombreamento arbóreo que proporcionava proteção total da radiação solar pelas fachadas secundárias.

No Sitio 1, a unidade arbórea de sombreamento era da espécie Licania Tomentosa/ Chrysobalanacea ou Oiti e, no Sítio 2, da espécie Mangifera indica ou Mangueira. As unidades arbóreas apresentavam mesma posição relativa em relação às salas (Figuras 02 e 03).

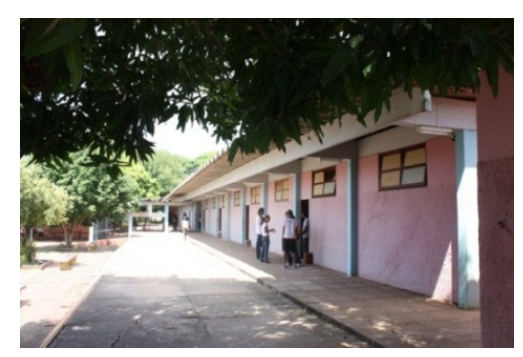

a)

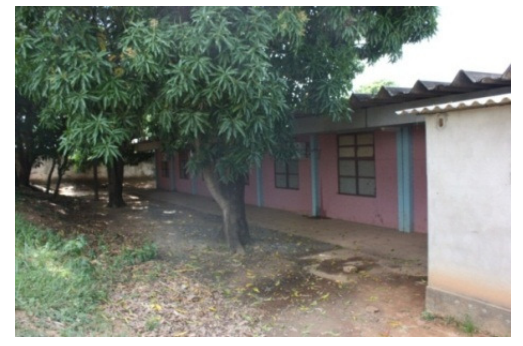

b)

Figura 02 - Fachada principal (83을 da sala sem sombreamento (a) e fachada secundária (263ํ) da sala com sombreamento por Mangueira (b) 


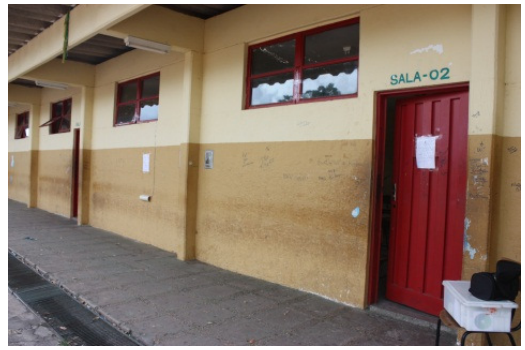

a)

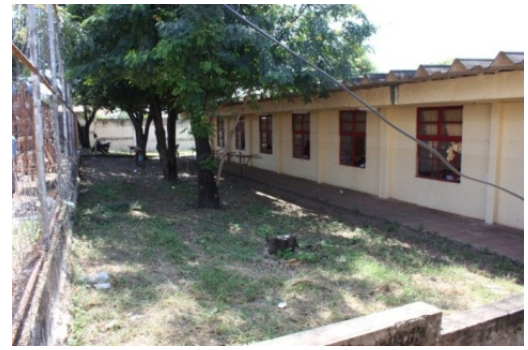

b)

Figura 03 - Fachada principal (138으) da sala sem sombreamento (a) e fachada secundária (318으) da sala com sombreamento por Oiti (b)

Externamente às edificações foram medidas temperatura de bulbo seco, umidade relativa do ar e temperatura de globo e iluminância ao sol e à sombra das unidades arbóreas, utilizando-se registradores automáticos HOBO U12-013 dispostos no interior de abrigos meteorológicos e HOBO UA002-64, para iluminância externa (Figura 04).

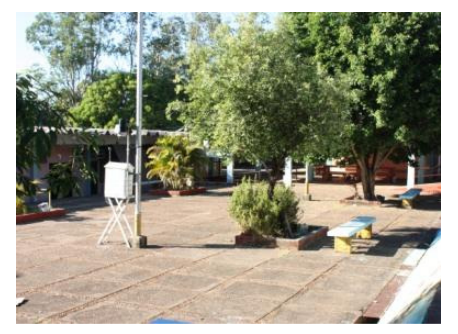

a)

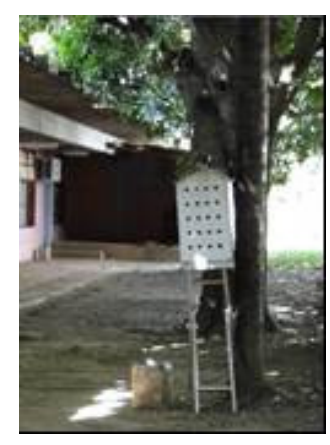

b)

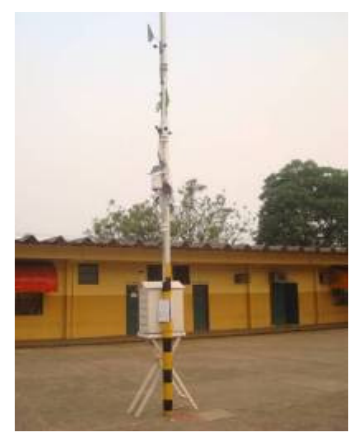

c)

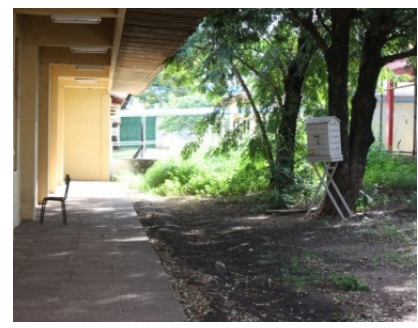

d)

Figura 04 - Abrigos termométricos no Sítio 1 a céu aberto (a) e sob a copa da Mangueira (b), no Sítio 2 a céu aberto (c) e sob a copa do Oiti (d)

No centro das salas com e sem sombreamento arbóreo foram medidas temperatura de bulbo seco, umidade relativa do ar, temperatura de globo, iluminância e temperatura superficial interna e externa da cobertura (face interna do forro em laje e face externa da telha de fibrocimento), utilizando-se registradores automáticos HOBO U12-012 e UA002-64.

As temperaturas de globo foram medidas por sensores TMC20HD, acoplados aos canais externos dos HOBO U12-013 e U12-012. A umidade absoluta foi calculada conforme COX (2008), aplicando-se as Equações 1 a 3, onde es é a pressão de saturação de vapor de água no ar (mbar), $T\left({ }^{\circ} \mathrm{C}\right)$ é a temperatura de bulbo seco $\left({ }^{\circ} \mathrm{C}\right)$, ear é a pressão de vapor de água no ar (mbar), UR é a umidade relativa do ar (\%), $T(K)$ é a temperatura de bulbo seco (K) e UA é a umidade absoluta do $\operatorname{ar}\left(\mathrm{g} \cdot \mathrm{m}^{-3}\right)$.

$$
\begin{array}{ll}
e_{s}=610,78 \cdot 10^{\frac{7,5, T(\bullet)}{237, z+T\left(\nabla^{C}\right)}}(m b a r) & \text { Equação } 1 \\
U R=\frac{e_{a r}}{e_{s} \cdot 100}(\%) & \text { Equação 2 }
\end{array}
$$




$$
U A=\frac{21 \% \cdot e_{a r}}{T(K)}\left(\mathrm{g} \cdot \mathrm{m}^{-3}\right)
$$

Equação 3

O Índice de Área Foliar (IAF) das unidades arbóreas de sombreamento das salas foi medido em outubro/2010, por meio do equipamento ceptômetro de barra modelo LP-80 AccuPAR, em horários de medição com altura solar próxima a $90^{\circ}$ e seguindo os procedimentos recomendados por DECAGON (2008). Com base no IAF, calculou-se a Área Foliar Total (AFT) como sendo o produto entre a densidade foliar e o volume da copa da árvore (OMETO, 1981).

Para a radiação solar global foram utilizados dados secundários de Callejas (2011).

Os equipamentos foram calibrados e sincronizados, com intervalo de medição de cinco minutos. O período de coleta de dados foi de 29/12/2010 a 23/01/2012 no Sítio 1 e de $30 / 12 / 2010$ a 23/01/2012, no Sítio 2, sendo portanto, correspondente à estação chuvosa. Durante as medições, as salas se encontravam desocupadas, sem a presença de iluminação e ventilação artificial, com janelas fechadas.

$\mathrm{Na}$ análise dos dados de temperatura e umidade do ar, utilizou-se o conceito matemático de variação relativa como recurso de normalização. Este conceito também foi utilizado por BuenoBartolomei e Labaki (2003) aplicado à variável radiação solar e por Ayres et al. (2004), aplicado à temperatura. A variação relativa pode ser definida como a atenuação ou acréscimo nas médias horárias de temperatura ou umidade do ar ao sol e à sombra, expressa em porcentagem (VR). 0 valor das médias horárias ao sol (SL) foi tomado como parâmetro de normalização conforme a Equação 4, onde SB são as médias horárias da temperatura ou umidade do ar sob a copa do indivíduo arbóreo $\left({ }^{\circ} \mathrm{C}\right)$.

$$
V R=\frac{S L-S B}{S I} \cdot 100(\%) \quad \text { Equação } 4
$$

A iluminância nos pontos de medição foi analisada segundo o conceito de Fator de Luz Diurna (FLD), definido como a iluminância difusa disponível em determinado ponto de referência ( $E_{p}$, em lux) e a iluminância difusa horizontal externa disponível na abóbada celeste ( $E_{\text {hext, }}$ em lux), expresso em \% conforme (VIANNA e GONÇALVES, 2001) e Equação 5.

$$
F L D=\frac{E_{p}}{E_{\text {hext }} \cdot 100}[\%]
$$

Equação 5

Os resultados foram analisados comparando-se os locais sombreados e não sombreados, relacionando-os ao índice de área foliar (IAF), área foliar total (AFT) e porte do indivíduo arbóreo.

\section{RESULTADOS}

A temperatura do ar a céu aberto apresentou máximas de 32,78 e $32,98^{\circ} \mathrm{C}$, médias de 27,44 e $27,70^{\circ} \mathrm{C}$ e mínimas de 24,24 e $24,61^{\circ} \mathrm{C}$, nos Sítios 1 e 2, respectivamente (Figura 05). Sob a sombra do Oiti, no Sítio 1 , a máxima, média e mínima foram de 29,23, 26,10 e 24,18 ${ }^{\circ} \mathrm{C}$, respectivamente. Sob a sombra da Mangueira, no Sítio 2, a máxima, média e mínima foram de $28,70,26,17$ e $24,52^{\circ} \mathrm{C}$, respectivamente. 


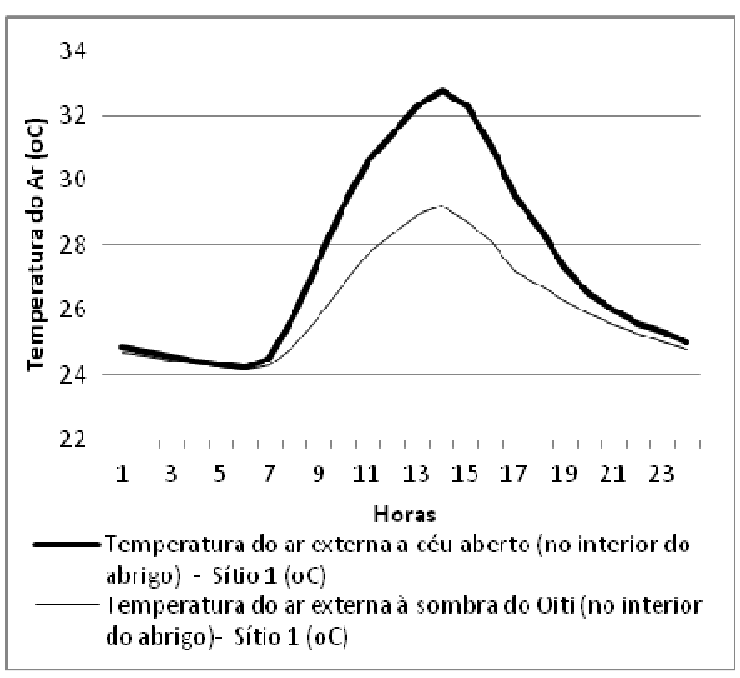

a)

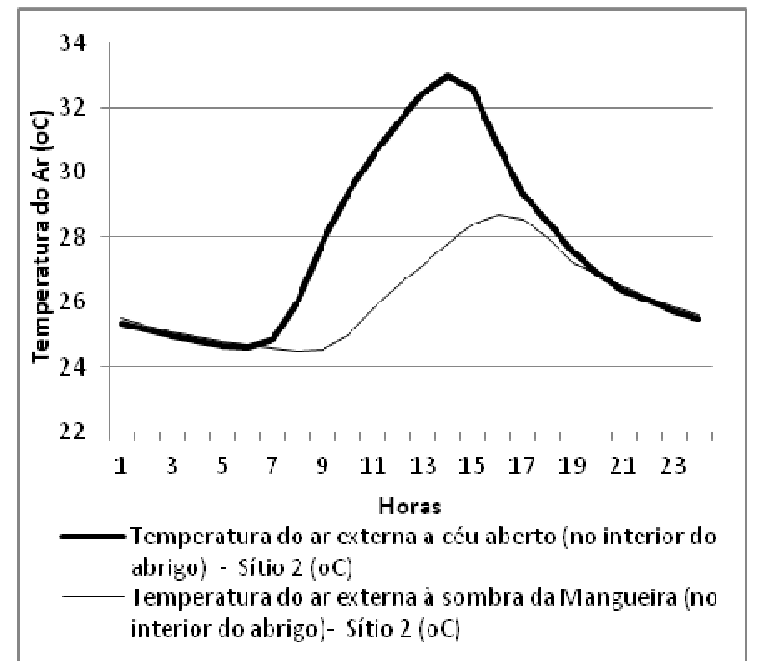

b)

Figura 05 - Médias horárias da Temperatura do Ar a céu aberto nos Sítios 1 (a) e 2 (b)

A umidade absoluta a céu aberto apresentou máximas de 20,93 e $21,67 \mathrm{~g} / \mathrm{m}^{3}$, médias de 20,11 e $20,66 \mathrm{~g} / \mathrm{m}^{3}$ e mínimas de 19,52 e $20,03 \mathrm{~g} / \mathrm{cm}^{3}$, nos Sítios 1 e 2 , respectivamente. Sob a sombra do Oiti, no Sítio 1, a máxima, média e mínima foram de 21,10, 20,69 e 20,20g/m respectivamente. Sob a sombra da Mangueira, no Sítio 2, a máxima, média e mínima foram de $21,41,20,70$ e $20,13 \mathrm{~g} / \mathrm{m}^{3}$, respectivamente (Figura 06).

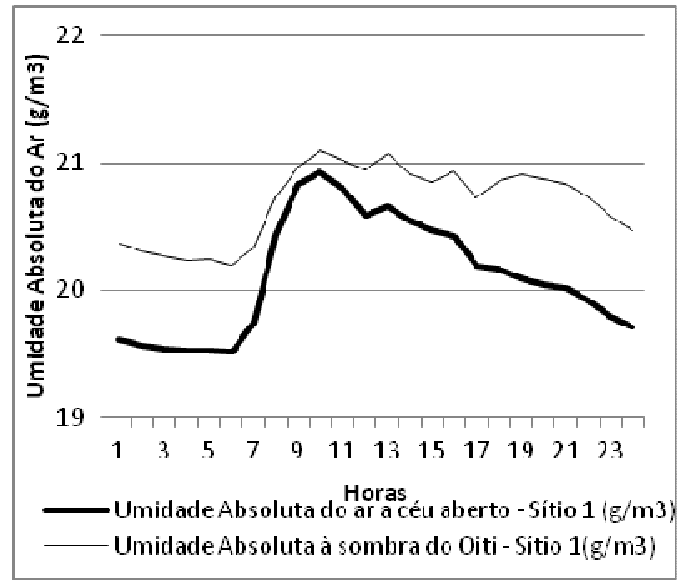

a)

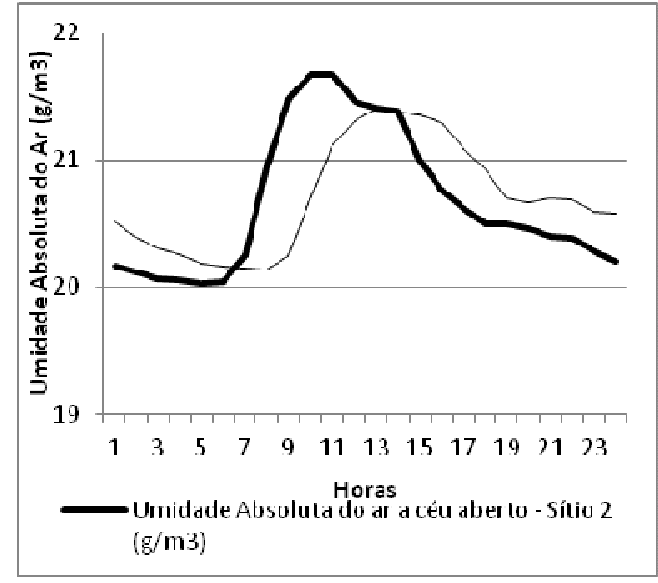

b)

Figura 06 - Médias horárias da Umidade Absoluta do Ar nos Sítios 1 (a) e 2 (b)

Os valores de temperatura e umidade do ar a céu aberto no Sítio 1 foram ligeiramente menores que no Sítio 2, o que pode ser justificado pela sua localização mais afastada do centro da cidade, onde a intensidade da ilha de calor urbana se manifesta com menor intensidade, como caracterizado por Maitelli (1994), Pinho (2003), Sanches (2005) e Callejas et al. (2011).

Sob os aspectos de atenuação da temperatura e acréscimos da umidade absoluta do ar sob a copa, o comportamento do Oiti ocorreu como esperado: a temperatura do ar, durante o período diurno, manteve-se sempre menor sob a copa que a céu aberto. No período noturno, as temperaturas sob a copa e fora dela se igualaram. Evidenciaram-se, assim, os efeitos da evapotranspiração: em condições normais de temperatura do ar e calmaria de vento, as folhas 
mantêm a sua temperatura menor que a do ar que as envolvem, utilizando para isso do recurso da transpiração, na qual liberam água para o meio. A umidade absoluta do ar na área sombreada manteve-se sempre acima da área exposta, confirmando a explicação acima.

$\mathrm{Na}$ Mangueira, o acréscimo da umidade absoluta sob a copa ocorreu no período vespertino e noturno, não sendo verificado no período matutino, muito embora a atenuação da temperatura do ar tenha se revelado de forma clara nos dados.

Verificou-se atraso térmico sob a copa da Mangueira de duas horas, decorrente do sombreamento da cobertura da edificação, implantada a leste-oeste. O período de medição coincidiu com o solstício de verão e a posição mais extrema do sol para o hemisfério sul, sendo que em função disso, a edificação proporcionou sombreamento no período matutino na região de medição à oeste da sala sombreada (Figura 07).

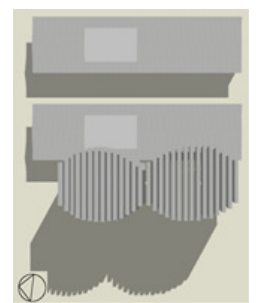

a)

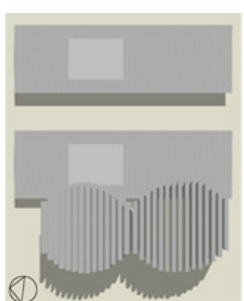

b)

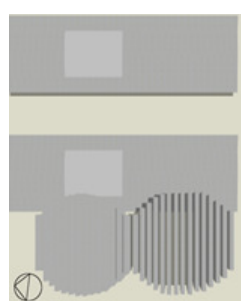

c)

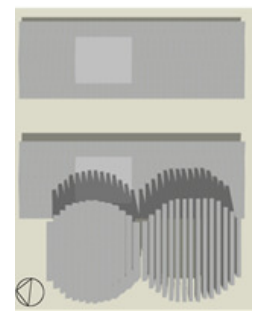

d)

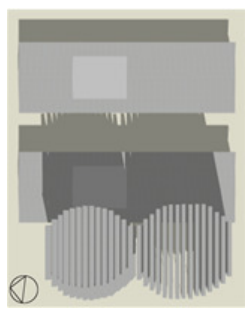

e)

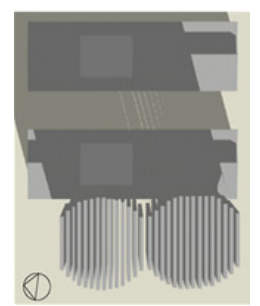

f)

Figura 07 - Sombreamento no Sítio 2 às $8 \mathrm{~h}(\mathrm{a}), 10 \mathrm{~h}(\mathrm{~b}), 12 \mathrm{~h}(\mathrm{c}), 14 \mathrm{~h}(\mathrm{~d}), 16 \mathrm{~h}(\mathrm{e})$ e $18 \mathrm{~h}(\mathrm{f})$ devido à própria edificação e à Mangueira, no solstício de verão

Fonte: Adaptado de Design Builder (2011)

Observando-se a incidência da radiação solar global nos Sítios 1 e 2, na Figura 08, tem-se as médias horárias da radiação solar global a céu aberto nos Sítios 1 e 2, sendo que no período noturno das 19 às $4 \mathrm{~h}$, havia presença de sistema de iluminação externa registrada pelo sensor em $0,6 \mathrm{~W} / \mathrm{m}^{2}$. No período diurno, das 5 às $18 \mathrm{~h}$, foi registrado máxima de 635,68 e $667,78 \mathrm{~W} / \mathrm{m}^{2}$, as 10 e $11 \mathrm{~h}$, nos Sítios 1 e 2, respectivamente. Observou-se no Sítio 1, valores ligeiramente menores que no Sítio 2, atribuídos à sua localização e, provavelmente relacionada à maior nebulosidade da região, que possui maior altitude (179 e 233m, respectivamente aos Sítios 1 e 2), sendo as diferenças estatisticamente não significativas (CALLEJAS, 2011).

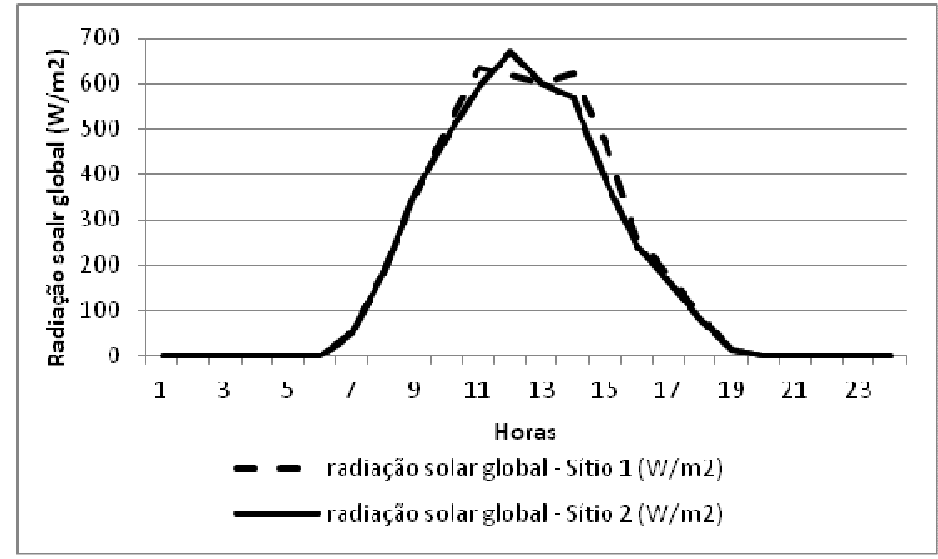

Figura 08 - Médias horárias da Radiação solar global nos Sítio s 1 e 2 
Sabe-se que a massa vegetada intercepta a radiação que entra na copa e a radiação que sai do solo, tendo um efeito marcante na temperatura e umidade do ar. As folhas verdes não aquecem tanto quanto o solo e trocam calor com o ar que as envolvem pela transpiração. Por consequência, durante os períodos de radiação líquida positiva, a temperatura próxima ao solo da área vegetada é reduzida. Já nos períodos noturnos, o ar junto ao solo é mais quente que acima das copas, onde a radiação líquida negativa é maior, justificado pelo efeito de barreira proporcionado pela copa, que bloqueia o movimento das camadas de ar e a liberação do calor radiante das superfícies aquecidas após o pôr do sol, resultando em temperaturas mais elevadas sob ela.

Tem-se, então, sob a copa um efeito oásis diurno e um efeito barreira (de abrigo) no período noturno, dependentes do porte e da arquitetura foliar. No caso dos indivíduos arbóreos estudados, o Oiti possuía 12,7m de projeção de copa, 3,98m de altura do fuste, 8,06m de altura de copa, IAF de $7,4 \mathrm{~m}^{2} \mathrm{~m}^{-2}$ e AFT de $842,5 \mathrm{~m}^{2}$. A Mangueira possuía $3,59 \mathrm{~m}$ de fuste, $7,38 \mathrm{~m}$ e de altura, $10,89 \mathrm{~m}$ de projeção de copa, IAF de $10,1 \mathrm{~m}^{2} \mathrm{~m}^{-2}$ e AFT de $940,7 \mathrm{~m}^{2}$. Desta forma, ambas as unidades arbóreas de sombreamento eram de grande porte (MASCARÓ e MASCARÓ, 2010).

O efeito da massa vegetada na temperatura sob a copa foi mais percebido na temperatura da Mangueira que no Oiti, por possuir maior área foliar total. Nela, ocorreu atenuação da temperatura do ar sob a copa durante o período de sol, chegando ao valor máximo de $16,30 \%$, às $12 \mathrm{~h}$, sendo que a noite, a temperatura sob a copa manteve-se maior que a céu aberto, com variação relativa negativa (Figura 09). No Oiti, a atenuação máxima no período diurno foi de $10,88 \%$ e se deu às $14 \mathrm{~h}$. Embora as temperaturas noturnas sob a copa do Oiti e a céu aberto ficassem com valores mais próximos, a temperatura sob a copa não superou a temperatura a céu aberto, mantendo-se a variação relativa positiva.

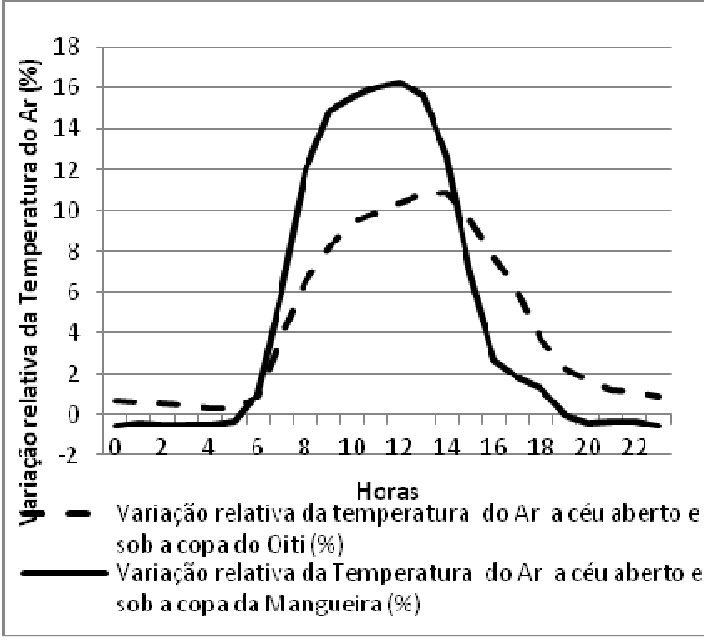

a)

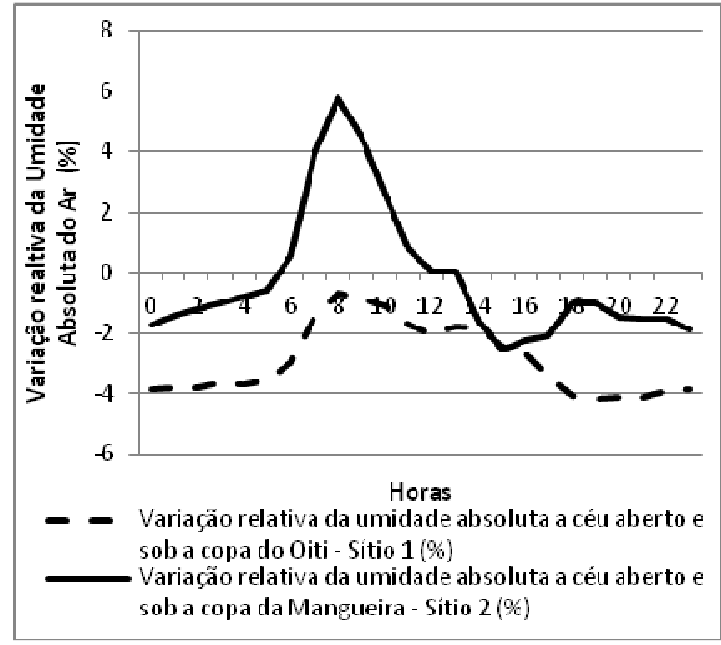

b)

Figura 09 - Médias horárias da variação relativa da Temperatura do Ar (a) e Umidade Absoluta do $\operatorname{Ar}($ b) nos Sítios 1 e 2

O efeito da vegetação na interceptação da radiação também foi verificada nas temperaturas de globo (Figura 10).

A céu aberto, nos Sítios 1 e 2, as temperaturas de globo máximas foram de 37,93 e $38,83^{\circ} \mathrm{C}$, as médias, de 28,69 e $29,20^{\circ} \mathrm{C}$ e as mínimas, de 23,94 e $24,18^{\circ} \mathrm{C}$, respectivamente. O Sítio 1 apresentou valores ligeiramente menores que o Sítio 2, acompanhando o comportamento da radiação solar global e temperatura do ar. 
Sob a copa do Oiti, as temperaturas de globo máxima, média e mínima foram de 30,00, 26,12 e $23,84^{\circ} \mathrm{C}$, respectivamente. Sob a copa da Mangueira, as temperaturas de globo máxima, média e mínima foram de $29,60,26,23$ e $24,19^{\circ} \mathrm{C}$, respectivamente.

Tendo em vista o porte semelhante das unidades arbóreas, as amplitudes das temperaturas de globo sob as copas foram semelhantes.

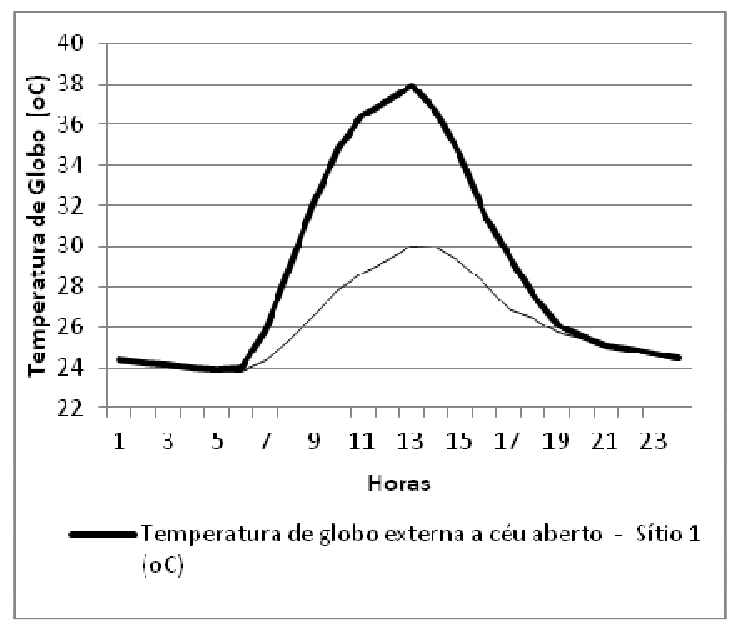

a)

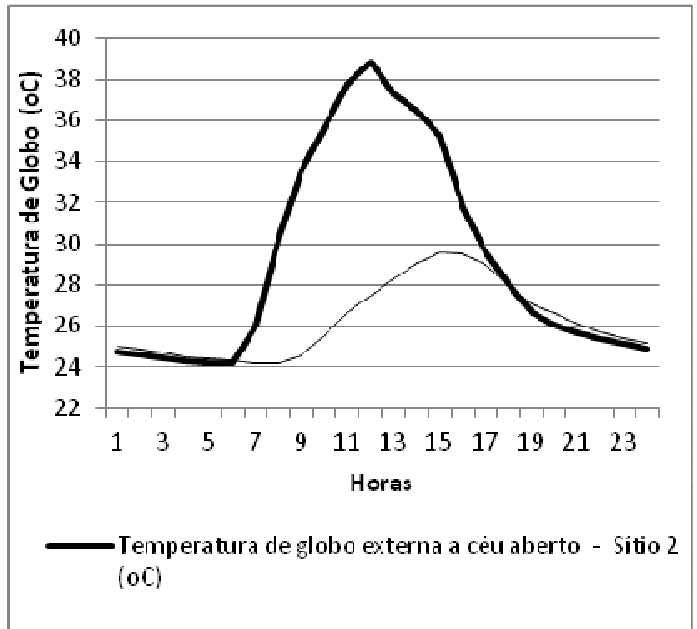

b)

Figura 10 - Médias horárias da temperatura de globo a céu aberto e sob a copa do Oiti, no Sítio 1 (a) e sob a copa da Mangueira, no Sítio 2 (b)

O sombreamento proporcionou redução nas temperaturas superficiais da cobertura (Figura 11).

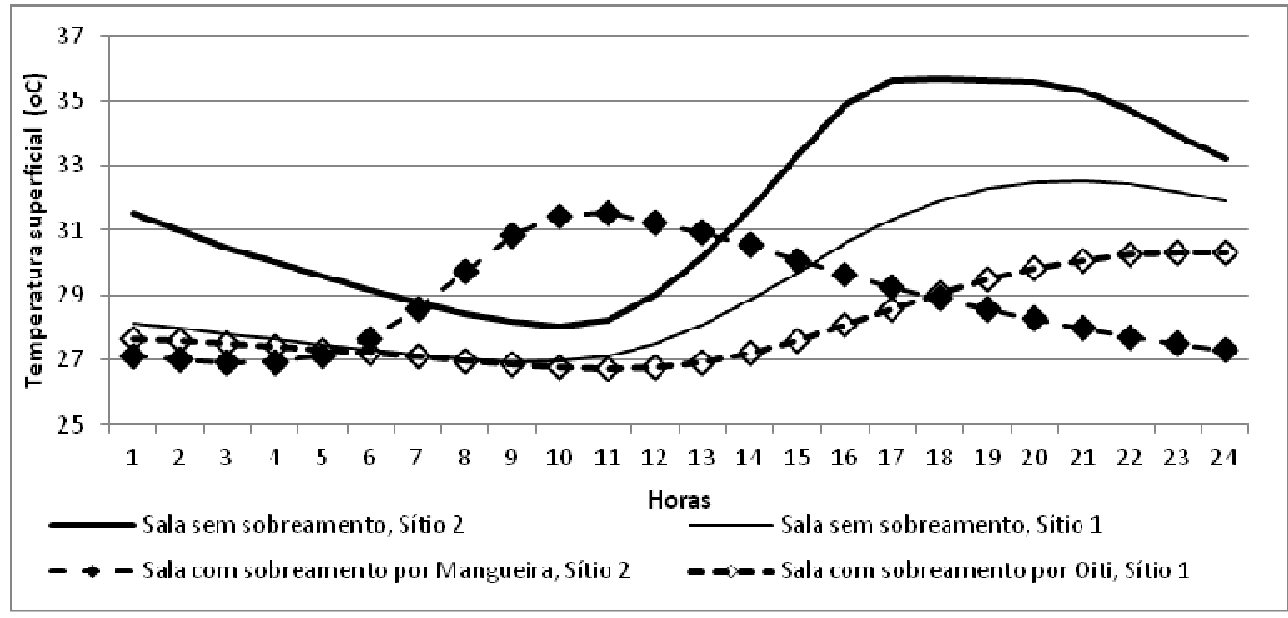

Figura 11 - Temperaturas superficiais na face externa e interna da cobertura das salas com e sem sombreamento

Na sala sem sombreamento do Sítio 2, obteve-se a temperatura superficial máxima da face interna do forro de $35,70^{\circ} \mathrm{C}$ às $18 \mathrm{~h}$ e a mínima de $28,03^{\circ} \mathrm{C}$, às $9 \mathrm{~h}$. Na sala sombreada, a máxima foi de $31,54^{\circ} \mathrm{C}$ às $10 \mathrm{~h}$ e a mínima de $26,91^{\circ} \mathrm{C}$ à $1 \mathrm{~h}$. A Mangueira de grande porte proporcionava efetivo sombreamento da cobertura da sala durante todo o período vespertino, 0 que justificou o amortecimento de $4,16^{\circ} \mathrm{C}$ e a defasagem de $6 \mathrm{~h}$ entre a ocorrência dos picos. 
Na sala sem sombreamento do Sítio 1, obteve-se temperatura superficial da face interna do forro máxima de $32,53^{\circ} \mathrm{C}$, as $20 \mathrm{~h}$ e mínima de $26,91^{\circ} \mathrm{C}$, às $8 \mathrm{~h}$. Na sala sombreada, mediu-se $30,32^{\circ} \mathrm{C}$, às $22 \mathrm{~h}$ e mínima de $26,75^{\circ} \mathrm{C}$, às $10 \mathrm{~h}$. O Oiti, embora tivesse porte semelhante, proporcionava sombreamento menos efetivo da cobertura, podendo ser distinguido amortecimento térmico de $2,21^{\circ} \mathrm{C}$ e atraso de $1 \mathrm{~h}$. O pico na sala exposta foi de $32,53^{\circ} \mathrm{C}$, às $20 \mathrm{~h}$ e na sala sombreada de $30,32^{\circ} \mathrm{C}$, às $22 \mathrm{~h}$.

O comportamento da temperatura superficial da cobertura ocorreu como esperado: como a árvore bloqueia o movimento do ar, a velocidade do ar e a taxa de resfriamento são menores na área sombreada que na exposta, explica-se o fato de que as diferenças entre as temperaturas superficiais dos forros das salas sombreadas e expostas (com taxa de resfriamento maior) diminuírem no período noturno. Ressalta-se que, à noite, a árvore inibe a troca de calor da parede com o ar (efeito de abrigo).

Como a cobertura é o principal componente de ganho de calor para o interior dos ambientes, seu sombreamento contribuiu decisivamente para a redução das temperaturas internas dos ambientes (Figura 12). O peso da cobertura no computo dos ganhos de calor é maior, tendo em vista que, embora as salas tivessem orientação de implantação distinta, as paredes não recebem radiação solar direta, devido à existência de amplos beirais.

No Sítio 1, na sala sem sombreamento, as temperaturas do ar máxima, média e mínima foram de $31,05,29,54$ e $28,12^{\circ} \mathrm{C}$. Na sala sombreada pelo Oiti, as temperaturas do ar máxima, média e mínima foram de $29,77,28,55$ e $27,38^{\circ} \mathrm{C}$, chegando-se a atenuação de $1,28^{\circ} \mathrm{C}$ na máxima, $1,58^{\circ} \mathrm{C}$ na média e $0,74^{\circ} \mathrm{C}$ na mínima.

Na sala sem sombreamento do Sítio 2 , as temperaturas do ar máxima, média e mínima foram de $32,95,30,93$ e $29,16^{\circ} \mathrm{C}$, respectivamente. Na sala sombreada pela Mangueira, as temperaturas do ar máxima, média e mínima foram de $30,88,29,35$ e $28,02^{\circ} \mathrm{C}$, respectivamente, chegando-se a atenuação de $2,07^{\circ} \mathrm{C}$ na máxima, $1,58^{\circ} \mathrm{C}$ na média e $1,14^{\circ} \mathrm{C}$ na mínima.

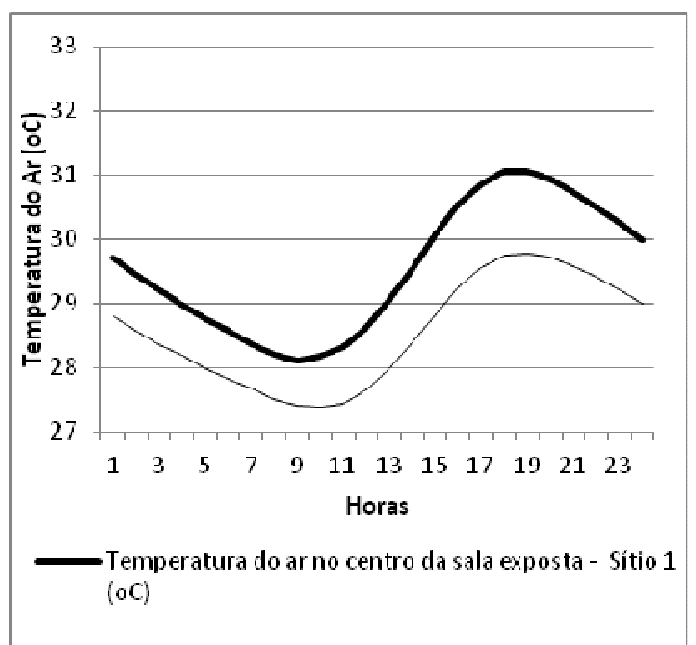

a)

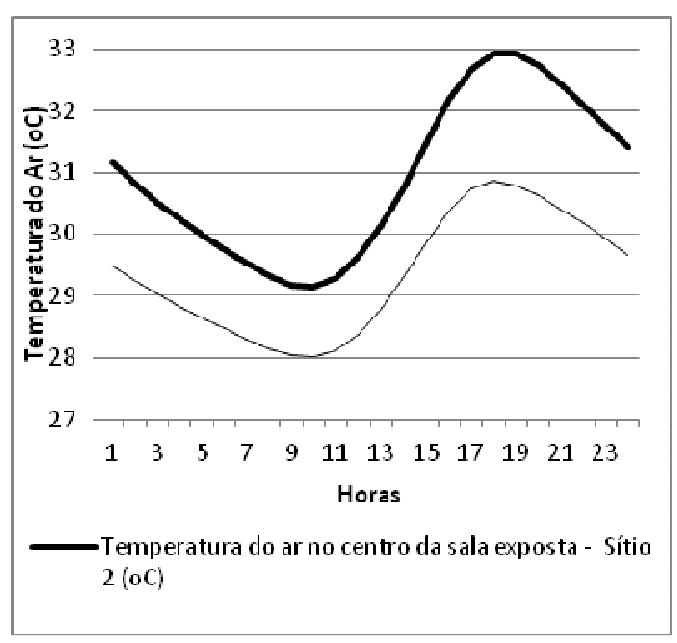

b)

Figura 12 - Temperatura do ar no centro das salas com e sem sombreamento no Sítio 1 (a) e Sítio 2 (b)

As superfícies externas sob o efeito da sombra da árvore se aquecem menos e, consequentemente, transmitem menos calor para o interior da sala. Como a radiação solar incidente nas superfícies sombreadas é menor que nas expostas, menor é a energia absorvida e 
transferida para o interior do ambiente e, consequentemente, melhores serão as condições termo higrométricas internas.

O efeito do sombreamento na temperatura sob a copa e no interior das salas foi analisado em termos do valor numérico e da variação relativa (Tabela 1).

Tabela 1 - Variação relativa da temperatura do ar

\begin{tabular}{|c|c|c|c|c|c|c|c|c|c|c|}
\hline \multirow[b]{2}{*}{$\begin{array}{l}\frac{0}{8} \\
\frac{0}{2} \\
\frac{0}{0}\end{array}$} & \multirow[b]{2}{*}{ Espécie } & \multicolumn{3}{|c|}{$\begin{array}{l}\text { Temperatura externa } \\
\left({ }^{\circ} \mathrm{C}\right)\end{array}$} & \multicolumn{3}{|c|}{$\begin{array}{l}\text { Temperatura interna } \\
\left({ }^{\circ} \mathrm{C}\right)\end{array}$} & \multicolumn{3}{|c|}{$\begin{array}{l}\text { Variação relativa da temperatura } \\
\text { (\%) }\end{array}$} \\
\hline & & $\begin{array}{l}\text { Céu } \\
\text { aberto }\end{array}$ & $\begin{array}{l}\text { Sob a } \\
\text { copa }\end{array}$ & $\begin{array}{l}\text { Dife- } \\
\text { rença }\end{array}$ & $\begin{array}{c}\text { Sala sem } \\
\text { sombrea- } \\
\text { mento }\end{array}$ & $\begin{array}{c}\text { Sala com } \\
\text { sombre- } \\
\text { amento }\end{array}$ & $\begin{array}{l}\text { Dife- } \\
\text { rença }\end{array}$ & $\begin{array}{c}\text { Céu aberto } \\
\text { e sob a } \\
\text { copa }\end{array}$ & $\begin{array}{c}\text { Céu aberto } \\
\text { e sala sem } \\
\text { sombrea- } \\
\text { mento }\end{array}$ & $\begin{array}{c}\text { Céu aberto } \\
\text { e sala com } \\
\text { sombrea- } \\
\text { mento }\end{array}$ \\
\hline 7 & Oiti & 29,27 & 27,01 & 2,26 & 28,87 & 27,94 & 0,93 & 7,72 & 1,37 & 4,54 \\
\hline $\begin{array}{l}\text { ds } \\
17 \mathrm{~h}\end{array}$ & Mangueira & 29,44 & 26,16 & 3,28 & 30,04 & 28,72 & 1,32 & 11,14 & $-2,04$ & 2,45 \\
\hline & Oiti & 32,30 & 28,95 & 3,35 & 29,05 & 27,99 & 1,06 & 10,37 & 10,06 & 13,34 \\
\hline $12 \mathrm{~h}$ & Mangueira & 32,44 & 27,15 & 5,29 & 30,15 & 28,81 & 1,34 & 16,31 & 7,06 & 11,19 \\
\hline 0 & Oiti & 27,44 & 26,10 & 1,34 & 29,54 & 28,55 & 0,99 & 4,88 & $-7,65$ & $-4,05$ \\
\hline $23 \mathrm{~h}$ & Mangueira & 27,70 & 26,17 & 1,53 & 30,93 & 29,35 & 1,58 & 5,52 & $-11,66$ & $-5,96$ \\
\hline
\end{tabular}

O sombreamento arbóreo do Oiti proporcionou redução na temperatura do ar de $1^{\circ} \mathrm{C}$, em média, entre as salas sombreadas e não sombreadas e da Mangueira de $1,4^{\circ} \mathrm{C}$, não havendo diferenças relevantes nos valores entre os períodos. Assim sendo, a atenuação da temperatura devido ao sombreamento do Oiti e Mangueira foi de 3,4 e 4,64\%, respectivamente.

Esse efeito pode ser medido pelas temperaturas de globo, que expressam o calor que atravessa os fechamentos por radiação (Figura 13).

No Sítio 1, a sala sem sombreamento arbóreo obteve temperaturas de globo máxima, média e mínima de $30,81,29,45$ e $28,16^{\circ} \mathrm{C}$ e a sala com sombreamento pelo Oiti, obteve temperaturas de globo máxima, média e mínima de $29,40,28,34$ e $27,3^{\circ} \mathrm{C}$, respectivamente.

No Sítio 2, a sala sem sombreamento arbóreo obteve temperaturas de globo máxima, média e mínima de $32,57,30,81$ e $29,22^{\circ} \mathrm{C}$ e a sala com sombreamento pela Mangueira, obteve temperaturas de globo máxima, média e mínima de $30,66,29,38$ e $28,20^{\circ} \mathrm{C}$, respectivamente. 


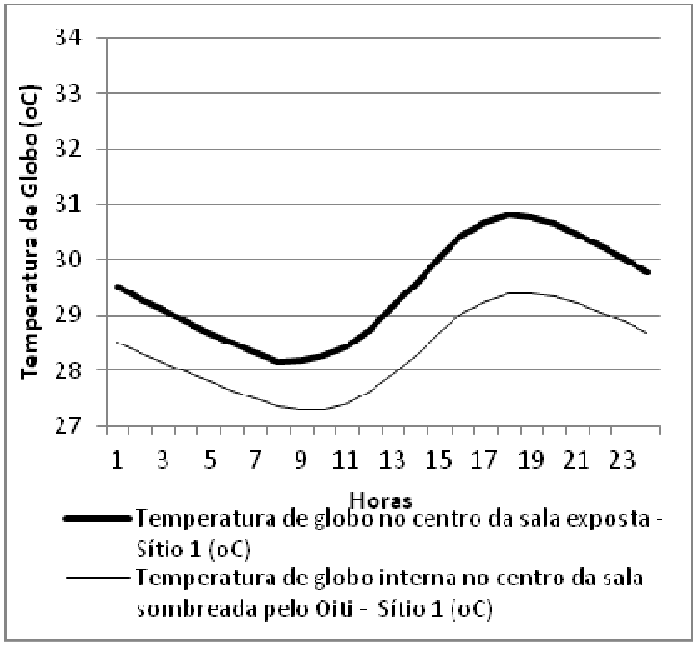

a)

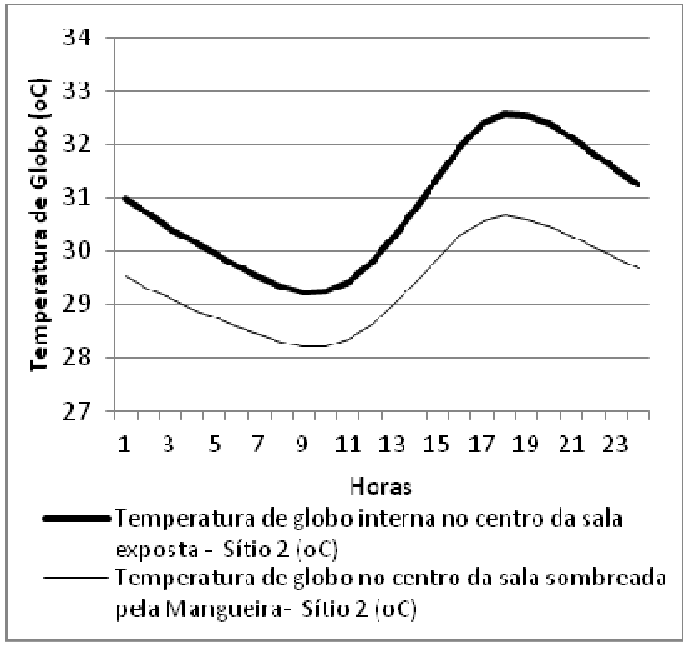

b)

Figura 13 - Temperatura de globo no centro das salas com e sem sombreamento nos Sítios 1 (a) e 2 (b)

Como as salas foram mantidas fechadas durante as medições, a renovações de ar foram mínimas e devidas somente às taxas de infiltração oriundas das frestas das esquadrias. Por isso, a umidade absoluta das salas sombreada e exposta sofreu pouca alteração (Figura 14).

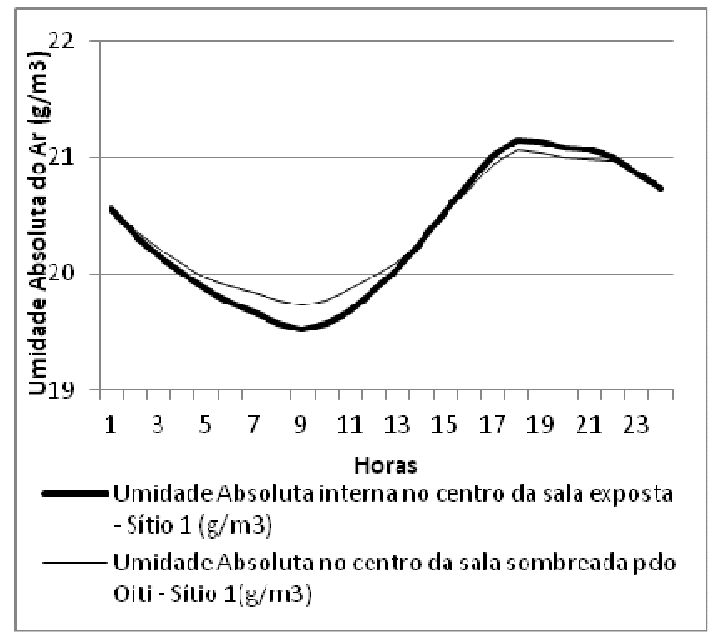

a)

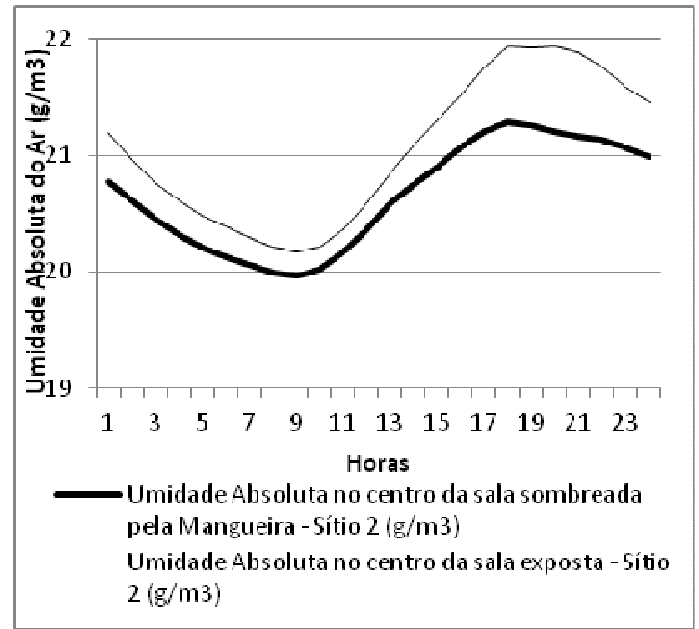

b)

Figura 14 - Umidade absoluta do ar no interior das salas expostas e sombreadas nos Sítio 1 (a) e 2

Juntamente com as perdas térmicas ocorrem perdas de iluminação natural das salas. Ao bloquear a radiação solar direta, a vegetação bloqueia, também, a luz visível. Se pelo lado positivo, o sombreamento proporciona diminuição dos ganhos térmicos no interior dos ambientes sombreados, pelo lado negativo de seu uso, proporciona perdas de luz natural, ambos proporcionalmente à qualidade da sombra. 
No Sítio 1, a céu aberto, a iluminância média externa máxima foi de 144.941,53 lux, às $12 \mathrm{~h}$, a média de $41.730,67$ lux e a mínima de 15,29lux, às $22 \mathrm{~h}$. Sob a copa do Oiti, a máxima foi de 9.872,99 lux, às $11 \mathrm{~h}$ e a média foi de 2820,91 lux ao longo do período das 6 às 18h (Figura 15).

No Sítio 2, a iluminância máxima foi de $140.949,81$ lux, às $12 \mathrm{~h}$, a média do período das 6 às $18 \mathrm{~h}$ foi de 40.832,42 lux e a mínima foi de 8,50 lux, às $6 \mathrm{~h}$. Sob a copa da Mangueira, a máxima foi de $6.485,98$ lux, às $14 \mathrm{~h}$ e a média foi de 1587,93 lux ao longo do período das 6 às 18h. No período noturno, sob ambas as copas, foi registrado 0 lux.

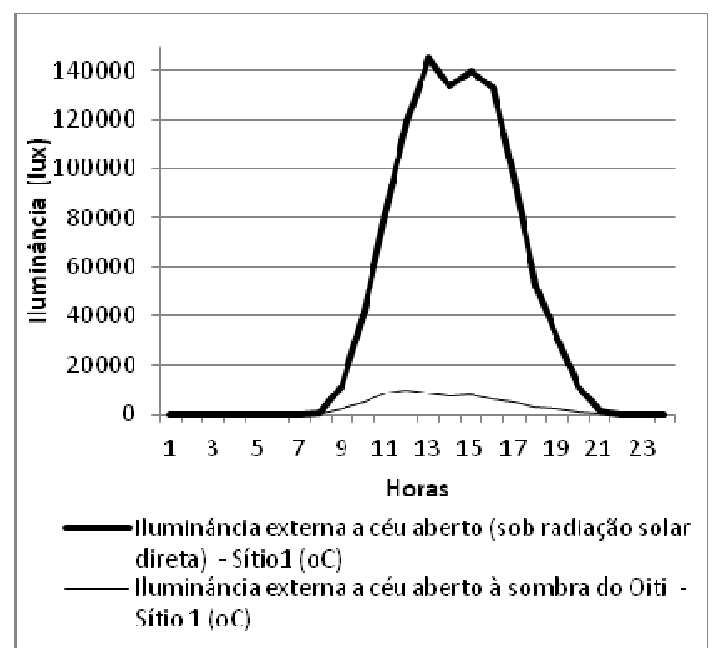

a)

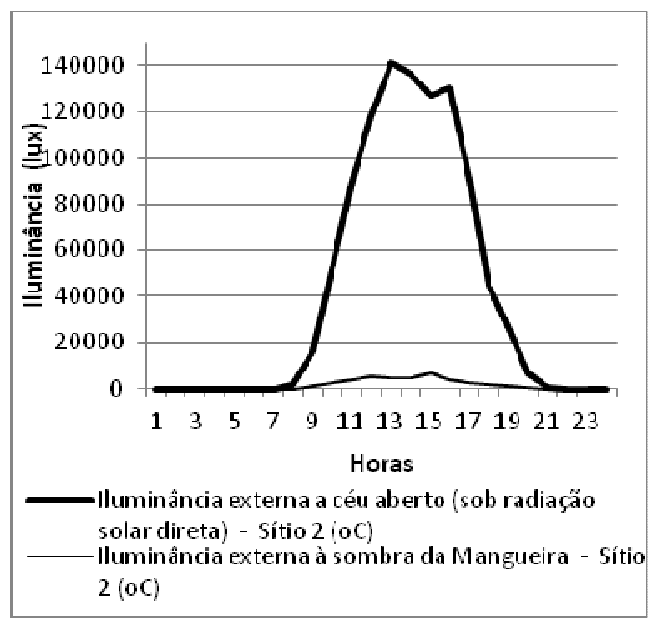

b)

Figura 15 - Médias horárias da iluminância externa ao sol e sob a copa do Oiti (a) e da Mangueira (b)

Nos período de 6 às 18h, a transmitância da luz pela copa do Oiti foi sempre maior que na Mangueira (Figura 16). Os valores médios ao meio-dia foram de 6,1 e 3,34\%, para o Oiti e Mangueira, respectivamente. A média do período de luz foi de 9,09 e 4,57\%, respectivamente ao Oiti e Mangueira, mantendo relação de proporcionalidade com a área foliar total, de $842,5 \mathrm{~m}^{2}$ e $940,7 \mathrm{~m}^{2}$, respectivamente ao Oiti e a Mangueira.

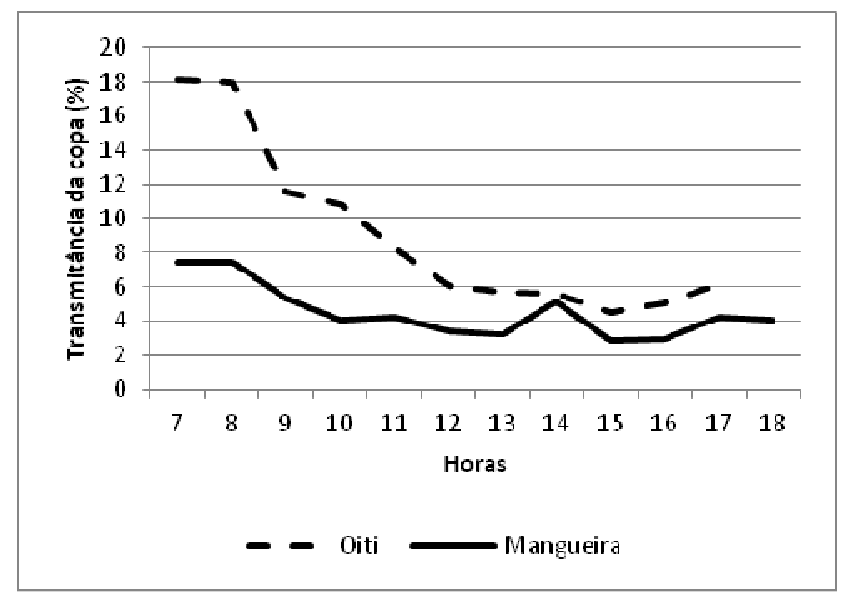

Figura 16 - Fração da radiação visível sob a copa para a Mangueira e Oiti 
Analisando-se a disponibilidade de luz natural média no interior das salas no período diurno, das 7 às 17h, tem-se o Fator de Luz Diurna (FLD) no centro das salas com e sem sombreamento (Figura 17).

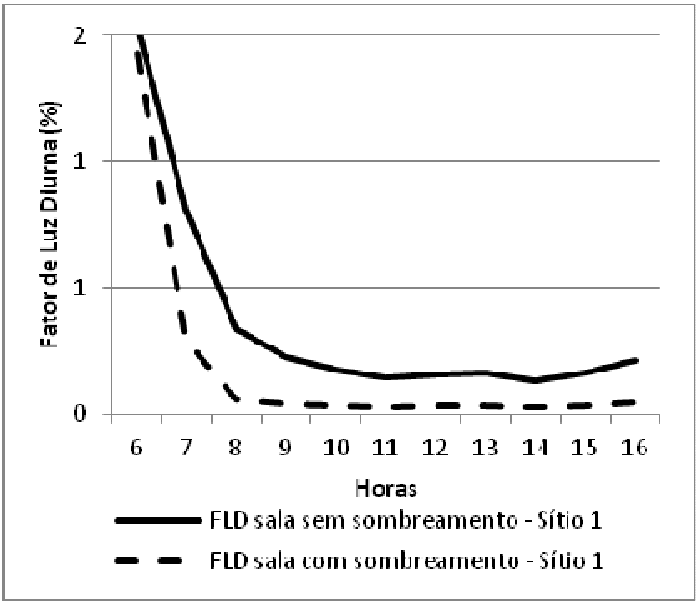

a)

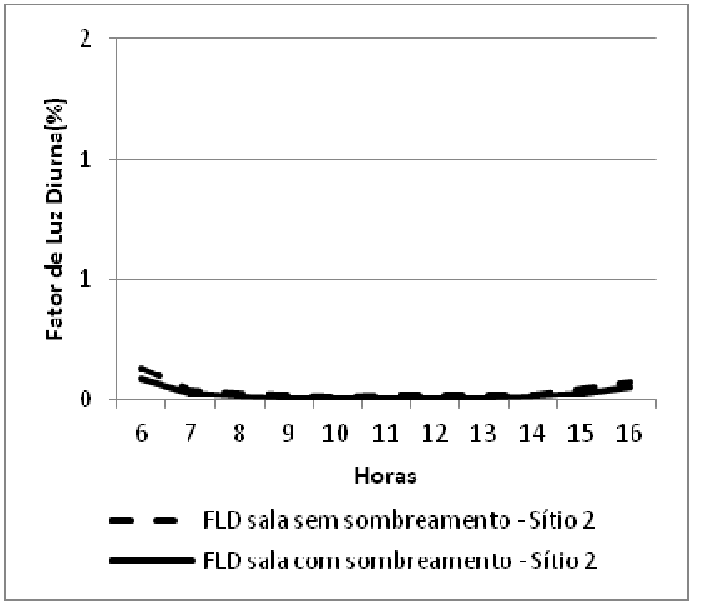

b)

Figura 17 - Fator de Luz Diurna nas salas com e sem sombreamento dos Sítios 1(a ) e 2 (b)

No Sítio 1 , nas fachadas orientadas a $138^{\circ}$ estavam dispostas janelas de $2,10 \mathrm{~m}$ de peitoril e nas fachadas orientadas a $318^{\circ}$, janelas com peitoril de $0,90 \mathrm{~m}$. A distribuição da luz ao longo da largura da sala foi assimétrica, com ocorrência de maior disponibilidade de luz no período matutino, incidindo pela janela alta da fachada 138‥

No Sítio 2, cujas fachadas e aberturas são orientadas a 83 e 263으, a distribuição da luz no centro da sala é simétrica, constituindo um aspecto positivo do ponto de vista do conforto lumínico e de funcionalidade da sala.

Ao meio dia, a disponibilidade de luz natural no centro das salas sem e com sombreamento do Sítio 1 era de 0,14 e 0,03\%. Considerando-se o período de 7 às $17 \mathrm{~h}$, o valor médio do FLD foi de 0,37 e 0,18\%, respectivamente (Tabela 2). No Sítio 2, a disponibilidade de luz natural no centro das salas sem e com sombreamento era de 0,02 e $0,01 \%$. Considerando-se o período de 7 as $17 \mathrm{~h}$, o valor médio do FLD foi de 0,11 e 0,09\%, respectivamente.

Tem-se, então, quantificado, que, ao meio dia, sob a copa da Mangueira, tem-se a menor quantidade de luz, 3,34\%, o que corresponde a uma perda de luz natural na sala sombreada de $50 \%$. No Oiti, a copa disponibiliza 9,09\% da iluminância a céu aberto e as perdas decorrentes do sombreamento foram de $21 \%$. 


\begin{tabular}{c|c|c|c|c|c}
\multicolumn{3}{|c|}{ Tabela 2 - Disponibilidade de luz natural sob as copas e no centro das salas } \\
Período & Espécie & $\begin{array}{c}\text { Fração de } \\
\text { luz sob a } \\
\text { copa } \\
(\%)\end{array}$ & $\begin{array}{c}\text { Fração de luz no } \\
\text { centro da sala sem } \\
\text { sombreamento } \\
\text { (\%) }\end{array}$ & $\begin{array}{c}\text { Fração de luz no } \\
\text { centro da sala com } \\
\text { sombreamento } \\
\text { (\%) }\end{array}$ & $\begin{array}{c}\text { Perda de luz natural } \\
\text { devido ao } \\
\text { sombreamento } \\
\text { (\%) }\end{array}$ \\
\hline \multirow{2}{*}{$\mathbf{7 - 1 7 h}$} & Oiti & 9,09 & 0,37 & 0,18 & 48 \\
\cline { 2 - 6 } & Mangueira & 4,57 & 0,11 & 0,09 & 82 \\
\hline \multirow{2}{*}{$\mathbf{1 2 h}$} & Oiti & 6,10 & 0,14 & 0,03 & 21 \\
\cline { 2 - 6 } & Mangueira & 3,34 & 0,02 & 0,01 & 50
\end{tabular}

Considerando-se o período de luz - 7 às $17 \mathrm{~h}$ - a disponibilidade sob a copa da Mangueira foi de $4,57 \%$ da iluminância a céu aberto e reduziu o FLD no centro da sala em $82 \%$. Sob a copa do Oiti, a disponibilidade de iluminância era de $9,09 \%$ da de céu aberto, o que provocou redução de $48 \%$ na disponibilidade de luz no centro da sala sombreada.

\section{CONCLUSÃO}

Sob a copa do Oiti e Mangueira, as temperaturas foram em média 2,3 e 3,3 $3^{\circ} \mathrm{C}$ menores que a céu aberto, respectivamente. No período noturno, as temperaturas sob a copa e fora dela se igualaram. A umidade sob a copa do Oiti manteve-se sempre maior que a céu aberto, sendo que este comportamento não pode ser evidenciado sob a copa da Mangueira, no período matutino.

Foi evidenciado sob as copas um efeito oásis diurno e um efeito barreira (de abrigo) no período noturno, dependentes do porte e da arquitetura foliar. A Mangueira, com IAF de $10,1 \mathrm{~m}^{2} \mathrm{~m}^{-2}$ e AFT de $940,7 \mathrm{~m}^{2}$, proporcionou maior atenuação da temperatura sob a copa que o Oiti, com IAF de $7,4 \mathrm{~m}^{2} \mathrm{~m}^{-2}$ e AFT de $842,5 \mathrm{~m}^{2}$, tendo, ambas as unidades arbóreas de sombreamento, grande porte.

Esse comportamento é decorrente da evapotranspiração da vegetação: a copa dos indivíduos arbóreos bloqueia a radiação solar e minimiza seus efeitos, diminuindo as temperaturas superficiais das áreas sombreadas. A transpiração das folhas contribui para a diminuição da temperatura do ar e consequente acréscimo de umidade. As superfícies externas sob efeito da sombra da árvore se aquecem menos e, consequentemente, transmitem menos calor para o interior da sala.

O sombreamento arbóreo do Oiti proporcionou redução na temperatura interna do ar interna das salas, de $1^{\circ} \mathrm{C}$ entre as salas sombreadas e não sombreadas e da Mangueira de $1,4^{\circ} \mathrm{C}$. $\mathrm{A}$ umidade absoluta manteve-se sempre maior na sala sombreada que na sala exposta.

Ao bloquear a radiação solar direta, a vegetação bloqueia, também, a luz visível. Considerando-se o período de luz - 7 às $17 \mathrm{~h}$, sob a copa do Oiti, a fração de luz externa disponível era de $9,09 \%$ e na Mangueira, de 4,57\%. O sombreamento reduziu a disponibilidade de luz na sala sombreada pela Mangueira em $82 \%$ e, pelo Oiti, em $48 \%$. De forma similar ao ocorrido com a temperatura, a atenuação da iluminância foi maior no sombreamento por Mangueira que possuía maior IAF e AFT.

Os resultados evidenciaram os efeitos positivos do sombreamento arbóreo nas condições termo higrométricas no interior e exterior das edificações. Ao se utilizar de sombreamento por vegetação, as contribuições estendem-se às estratégias de resfriamento evaporativo e umidificação, ampliando seus benefícios para o microclima do entorno, proporcionando 
ambientes externos mais atrativos e adequados ao uso, que podem minimizar os efeitos do intenso processo de urbanização por qual passam as cidades.

Sob os aspectos das condições lumínicas, tendo em vista a grande disponibilidade de luz natural na cidade de Cuiabá, é possível dimensionar as aberturas e a vegetação de sombreamento quanto ao seu porte, posicionamento e qualidade de sombra, considerando-se sistemas de iluminação artificial integrados, de forma a compensar as perdas de luz natural oriundas do sombreamento.

\section{AGRADECIMENTO}

À ELETROBRAS pelo apoio financeiro no desenvolvimento desta pesquisa.

\section{REFERÊNCIAS}

AYOADE, J. O. Introdução a climatologia para os trópicos. Rio de Janeiro: Bertrand Brasil, 332p, 2001.

AYRES, M. C. R. TARGA, L. A., PEIXOTO, P. P. P. Influência do sombreamento natural da Sibipiruna (Caesalpinia peltrophoroides) na temperatura de edificações. In: Energ. Agric. Botucatu, vol. 20, n. 1, p. 62-76, 2005.

BORGES, M. G. E. Influência do ambiente construído no microclima urbano - Estudo de caso no Campus da Universidade Federal de Santa Catarina-Florianópolis. 2009. 154 p. Dissertação (Mestrado em Arquitetura e Urbanismo)- Universidade Federal de Santa Catarina.

BUENO-BARTHOLOMEI, C. L.; LABAKI, L. C. How Much does the Change of Species of Trees Affect their Solar Radiation Attenuation? In: INTERNATIONAL CONFERENCE ON URBAN CLIMATE, 5, 2003, Lodz. Proceedings... Lodz: IAUC, 2003. v. 1. p. 267-270.

CALLEJAS, I. J. A. Balanço de energia em ambientes urbanos na cidade de Cuiabá-MT. 2011. Tese (Doutorado em Física Ambiental). Instituto de Física, Universidade Federal de Mato Grosso, Cuiabá-MT.

CALlejAS, I. J. A.; DURANTE, L. C.; OliveiRA, A. S.; NOGUEIRA, M. C. J. A. Uso do solo e temperatura superficial em área urbana. Mercator, Fortaleza, v. 10, n. 23, p. 207-223, 2011.

CALlejAS, I. J. A. DURANTE, L. C., NOGUEIRA, M. C. A., NOGUEIRA, J. S CAMPOS, A. C. S. Estudo do sombreamento arbóreo, atenuação da radiação solar e microclima dos pátios escolares: elementos para se pensar a sustentabilidade urbana. In: Encontro Latino Americano de Construções Sustentáveis, 2011, Vitória. Anais... Vitória, v.1, p. 1 - 10, 2011.

CHARLES-EDWARDS, D. A.; THORNLEY, J. H. M. Light Interception by an Isolated Plant: A Simple Model. Lillehampttin, Sussex Received: 6 December 1972.

CHEN, Y. The intervention of plants in the conflicts between buildings and climate - A case study in Singapore. 2006. 336f. Thesis (Doctor in Philosophy). Department of Building, National University of Singapore, Singapore. 
COX, E. P. Interação entre clima e superfície urbanizada: o caso da cidade de Várzea Grande/MT. 2008. Dissertação (Mestrado em Geografia). Instituto de Ciências Humanas e Sociais, Universidade Federal de Mato Grosso, Cuiabá-MT.

CRUZ, G. C. F.; LOMBARDO, M. A. A importância da arborização para o clima urbano. In: II Seminário Nacional Sobre Regeneração Ambiental de Cidades - Água Urbanas II, 2007, Londrina. Anais... Londrina, 2007. CD-ROM.

DECAGON. Accupar - PAR/LAI Ceptometer. Operator's Manual. Version 6. 2008.

DESIGN BUILDER. DesignBuilder Software Ltda. Versão 3.0.0.064. 2009.

DUARTE, D. H. S., SERRA, G. G. Padrões de ocupação do solo e microclimas urbanos na região de clima tropical continental brasileira: correlações e proposta de um indicador. Ambiente Construído, Porto Alegre, v. 3, n. 2, p. 7-20, 2003.

GIVONI, B. Comfort Climate Analysis and Building Design Guidelines. Energy and Buildings, v. 18, n. 1, 1992.

KOENIGSBERGER, O. H. Manual of tropical housing and building. New York: Longman, 1974.

LIMA, D.C.R. Monitoramento e desempenho da vegetação no conforto térmico em espaços livres urbanos: o caso das praças de Maringá/PR. 2009. 170 p. Dissertação (Mestrado em Engenharia Urbana) - Universidade Estadual de Maringá, Maringá.

MASCARÓ, L.; MASCARÓ, J. L. Vegetação Urbana. Porto Alegre: Masquatro. 3a ed. 212p., 2010.

OMETO, J. C. Bioclimatologia Vegetal. São Paulo: Agronômica Ceres Ltda, 1981.

SANT'ANNA NETO, J. L. Mudanças Climáticas Globais: Implicações no Desenvolvimento Econômico e na Dinâmica Natural. Revista Pantaneira, v. 2, n. 2, p. 66-78, 2000.

TORRES, S. C.; LISBÔA, T. A., BARBIRATTO, G. M. Microclimas em ruas e praças em Maceió - AL. In: VII Encontro Nacional Sobre Conforto no ambiente Construído e II Conferência Latino Americana Sobre Conforto e Desempenho Energético de Edificações, 2003, Curitiba. Anais... Curitiba, p. 600607, 2003.

VIANNA, N. S., GONÇALVES, J. C. S. Iluminação e Arquitetura. São Paulo: Virtus S/C Ltda. 2001.

YANG, Z. L.; DAI, Y.; DICKINSON, R. E.; SHUTTLEWORK, W. J. Sensitivity of ground heat flux to vegetation cover fraction and leaf area index. Journal of Geophysical Research, v. 104, n. D16, p. 19,505-19,514, August 27, 1999.

YOSHIMI, I.; ALTAN, H. THERMAL SIMULATIONS on the effects of vegetated walls on indoor buildings environments. In: Proceedings of Building Simulation, 12th Conference of International Building Performance Simulation Association, Sydney, 14-16, November. 
Identificação dos Autores:

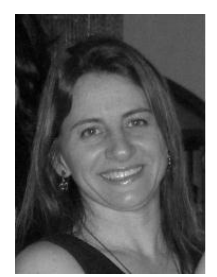

Luciane Durante

Graduação em Engenharia Civil pela Universidade Federal de Mato Grosso/ UFMT;

Professora Efetiva do Departamento de Arquitetura e Urbanismo/ UFMT;

Doutora pelo Programa de Pós Graduação em Física Ambiental/ PPGFA/ UFMT, Linha de Pesquisa: Análise

Microclimática em Sistemas Urbanos, E-mail: luciane.durante@hotmail.com

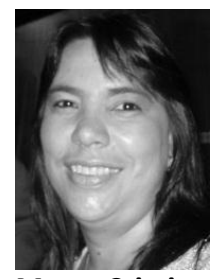

Marta Cristina de Jesus Albuquerque Nogueira

Graduação em Engenharia Civil pela Universidade Federal de Mato Grosso/ UFMT;

Professor Efetiva do Departamento de Arquitetura e Urbanismo/ UFMT;

Professora do Programa de Pós Graduação em Física Ambiental/ PPGFA/ UFMT, Linha de Pesquisa: Análise Microclimáticas em Sistemas Urbanos, E-mail: mcjanp@gmail.com 